\author{
Maciej DAWCZYK \\ Uniwersytet Łódzki \\ maciejdawczyk@gmail.com
}

\title{
GRANICE PAŃSTWA KOŚCIELNEGO W II POŁOWIE VIII WIEKU W ŚWIETLE WCZESNYCH ŹRÓDEE HISTORYCZNYCH
}

ABSTRACT Borders of the Papal State in the Second Half of $8^{\text {th }}$ Century in the Light of Early Sources

In 756 as the result of donation made by frankish king Pepin papacy formally controlled duchy of Rome, part of former exarchate of Ravenna (earlier directly submitted to Ravenna), larger part of duchy of the Pentapolis and probably duchy of Perugia. Papacy claimed belonged to Lombards territory of plenaria iustitiae (part of Pentapolis and duchy of Ferrara) as well. In 765 king Desiderius transfered to papacy not plenaria iustitiae but some parts of Tuscany, duchy of Benevento and duchy of Spoleto. In 774 took place frankish intervention which destroyed lombard kingdom. Frankish king Charlemagne conveyed to pope Hadrian I new territories (lombard Tuscany, Corsica, Spoleto, Benevento, Istria, Veneto) and confirmed old donations. However the pope had not possibility to really take over these lands. In 781 as the recompensation king conveyed to Hadrian southern part of Lombard Tuscany, territory of Sabina, part of Campania and confirmed territories in exarchate and Pentapolis. Corsica, Sardinia and Sicily were added as well. In 787 papacy received next part of Campania. Determination of the shape of the territories practically controlled by the pope is very difficult because in many lands there were problems with introduction of real papal reign.

Keywords: papal state, papacy, Franks, Lombards, middle ages

Słowa kluczowe: Państwo Kościelne, papiestwo, Frankowie, Longobardowie, średniowiecze 


\section{ZAŁOŻENIA WSTĘPNE I BAZA ŹRÓDŁOWA}

Celem artykułu jest przede wszystkim próba rekonstrukcji zakresu terytorialnego posiadłości papiestwa w VIII w. na podstawie wczesnych źródeł historycznych (do lat 20. VIII w.), zawierających szczegółowe wykazy miejscowości i obszarów, które znajdować się miały pod kontrolą Stolicy Apostolskiej lub do których papiestwo rościło sobie pretensje. By prezentowana problematyka była zrozumiała, niezbędne jest jednak również przedstawienie procesu formowania się niezależnego Państwa Kościelnego oraz uwarunkowań politycznych, które wpływały na kształtowanie się jego granic. Stanowiąca podstawę rozważań baza źródłowa nie jest szeroka, dostarcza jednak obszernych informacji. Pominięte zostały późniejsze spisy terytoriów przynależnych Stolicy Piotrowej (np. zawarty w Privilegium Ottonianum), ze względu na swą wtórność wobec źródeł wcześniejszych bądź nikłą adekwatność do realiów omawianego w artykule okresu.

Jako pierwsze źródło wymienić można kronikę pontyfikatów papieży znaną jako Liber Pontificalis ${ }^{1}$. Stanowi ona zbiór biogramów biskupów Rzymu od czasów św. Piotra po 891 r., tworzonych przez anonimowych autorów wywodzących się z kręgu kurii rzymskiej. Liber Pontificalis w pierwotnej wersji (do dziś zachowało się kilka redakcji) skompilowano w czasach Feliksa IV (526-530) albo Grzegorza Wielkiego (590-604), a następnie biogramy papieży tworzone były na bieżąco, najczęściej tuż po śmierci danego pontyfika. Źródło to ma charakter dość tendencyjny, jego twórcy byli bowiem podwładnymi papieży i przyjmowali zawsze punkt widzenia przychylny Rzymowi. Zawarte w nim informacje dotyczące treści porozumień kształtujących terytorium Państwa Kościelnego wydają się jednak stosunkowo wiarygodne. Choć przejęcie przez Rzym kontroli nad częścią wymienionych tam ziem napotykało trudności (co odzwierciedla papieska korespondencja $\mathrm{z}$ frankijskim dworem, a autorzy Liber Pontificalis wstydliwie bądź z wyrachowania pomijają milczeniem), to sam fakt, że papieże dość śmiało zabiegali w tych kwestiach o pomoc Franków, może świadczyć, iż mieli ku temu odpowiednią podstawę formalną, prawdopodobnie w postaci wymienionych w kronice porozumień. Z punktu widzenia tematyki granic Państwa Kościelnego w VIII w. istotne są zawarte w Liber Pontificalis biogramy papieży Stefana II i Hadriana I.

Istotne informacje znajdują się także w zbiorze Codex Carolinus ${ }^{2}$. Zawiera on kopie listów, które na dwór majordomów i królów frankijskich słali papieże od czasów Grzegorza II aż po końcowy etap pontyfikatu Hadriana I (791 r.). Skompilowany został

Liber Pontificalis I-XCVI (usque ad annum 772) [Księga Pontyfików 1-96 (do roku 772)], tekst laciński i polski, przeł. P. Szewczyk, M. Jesiotr, Kraków 2014 [dalej: LP]; Liber Pontificalis XCVII-CXII (ann. 772-891) [Ksiegga Pontyfików 97-112 (772-891)], tekst łaciński i polski, przeł. A. Caba, B. Frontczak, M. Jesiotr, Kraków 2015 [dalej: LP]; zob. też L. Capo, Il Liber Pontificalis, I longobardi e la nascita del dominio territoriale della chiesa romana, Spoleto 2009, s. 3-112; T.F.X. Noble, New Look at the Liber Pontificalis, „Archivum Historiae Pontificiae” 1985, vol. 23, s. 347-358; M. Ożóg, H. Pietras, Wprowadzenie, [w:] LP I-XCVI, s. V-XVIII.

2 Codex Carolinus [dalej: CC], [w:] Monumenta Germaniae Historica, Epistolae (3), Epistolae Merowingici et Karolini aevi (I), red. W. Gundlach, Berolini 1892; zob. też D. Jasper, H. Fuhrmann, Papal Letters in the Early Middle Ages, Washington D.C. 2001, s. 104-108. 
najprawdopodobniej właśnie w 791 r. w Kolonii i znalazło się w nim 99 pism. Niestety nie są one datowane, a datacja sugerowana przez wydawców jest tylko hipotetyczną rekonstrukcją. Spora liczba zawartych w zbiorze dokumentów zawiera informacje na temat prób wyegzekwowania przez papieży swojej władzy na wielu terytoriach, do których zgłaszali roszczenia. W kontekście terytorium Państwa Kościelnego źródło to cechuje się dużą dozą wiarygodności. Zawarte w nim listy powstawały bowiem, gdyż papiestwo dążyło do osiągnięcia doraźnych celów politycznych w postaci rozszerzenia zakresu terytorialnego władzy papieża. W tej sytuacji na dalszy plan schodziły aspekty prestiżowe i biskupi Rzymu bez ogródek pisali o problemach z wyegzekwowaniem swego autorytetu, byle tylko uzyskać pomoc lub skłonić Franków do zmiany postępowania.

Ważne wiadomości dotyczące terytorium Państwa Kościelnego zawarte zostały również w dokumencie noszącym nazwę Pactum Ludovicianum, powstałym w 817 r. $^{3}$ Stanowił on potwierdzenie układu zawartego między synem Karola Wielkiego Ludwikiem Pobożnym a papieżem Stefanem IV. W wyniku szybkiej śmierci Stefana porozumienie zostało konfirmowane już przez nowego papieża - Paschalisa I. Tekst dokumentu dotyczy darowizn terytorialnych poczynionych przez Franków na rzecz Państwa Kościelnego od 756 r. Dodatkowo Ludwik zagwarantował papiestwu różne swobody, takie jak np. swoboda elekcji biskupa Rzymu. Do ideologicznego aspektu treści porozumienia należy podchodzić jednak z pewną dozą ostrożności, ponieważ najwcześniejszy znany manuskrypt pochodzi z XI-wiecznego kodeksu prawa kanonicznego, tekst mógł więc zostać nieco zmodyfikowany, tak by odpowiadać ówczesnemu zapotrzebowaniu politycznemu - jego powstanie przypada bowiem na czasy początku silnego konfliktu papiesko-cesarskiego (sporu o inwestyturę). W kwestii nabytków terytorialnych papiestwa tekst prawdopodobnie w dużym stopniu odzwierciedla stan faktyczny (jest zbieżny z wieloma fragmentami Liber Pontificalis i Codex Carolinus; niektóre inne wymienione nabytki wydają się logiczną konsekwencją pewnych uwarunkowań zachodzących w relacjach między papieżem a Frankami), choć znajdują się w nim także elementy mało wiarygodne, będące zapewne jedynie emanacją ambicji papiestwa i cesarstwa.

\section{GENEZA PAŃSTWA KOŚCIELNEGO}

Termin „Państwo Kościelne” nie pojawia się we wczesnośredniowiecznych źródłach. Sami papieże używali w tym czasie dla określenia swojego władztwa nawiązującej do tradycji antycznych formuły Republika Rzymska (Sancta Dei ecclesia, res publica romanorum), określając też swoje ziemie jako patrymonium św. Piotra ${ }^{4}$. Twór pod zarządem

Pactum Hludovicii Pii cum Paschali pontefice [dalej: Pactum], [w:] Monumenta Germaniae Historica, Capitularia regum Francorum (1), Additamenta ad Hludowici Pii et Hlotharii Capitularia (XI), red. A. Boretius, Hannoverae 1883; zob. też. C. Goodson, The Rome of Pope Paschal I: Papal Power, Urban Renovation, Church Rebuilding and Relic Translation, 817-824, Cambridge 2010, s. 30-34.

4 D.H. Miller, The Roman Revolution of the Eighth Century: A Study of the Ideological Background of die Papal Separation from Byzantium and Alliance with the Franks, "Mediaeval Studies” 1974, vol. 36, s. 119-133. 
papieża, który powstał na obszarze środkowej Italii w wyniku dwóch interwencji militarnych przeprowadzonych przez frankijskiego króla Pepina III Małego w latach 755-756, mimo pewnej niedookreśloności terminologicznej był jednak dość samodzielnym podmiotem politycznym (choć opierającym się na frankijskiej protekcji) o przynajmniej z grubsza zarysowanych granicach i strukturze władzy 5 .

Pierwsze poważniejsze rozdźwięki między papiestwem a chrześcijańskimi już od pewnego czasu władcami cesarstwa rzymskiego zaczęły pojawiać się w IV w. Początkowo spory miały charakter doktrynalny - niektórzy cesarze tego okresu (Konstancjusz II, Walens) skłaniali się bowiem ku ariańskiej odmianie chrześcijaństwa. Choć pod koniec wieku wpływy ariańskie osłabły, pojawiło się kolejne źródło niesnasek. Ugruntowaniu się środka politycznej ciężkości cesarstwa w Konstantynopolu towarzyszył bowiem wzrost pozycji miejscowej hierarchii kościelnej. Biskup Nowego Rzymu szybko uzyskał tytuł patriarchy oraz status niemalże równy papieskiemu, ustępując jedynie honorowego pierwszeństwa. W tej sytuacji Stolica Piotrowa zaczęła obawiać się marginalizacji. Konsekwencją takiego stanu rzeczy było pojawienie się koncepcji wyższości władzy papieskiej nad cesarską, tezy po raz pierwszy wyraźnie wyartykułowanej przez papieża Gelazego (492-496). Negatywnie na relacje między Stolicą Apostolską a władzą cesarską w Konstantynopolu wpływała też przychylna wobec monofizyckiego odłamu chrześcijaństwa polityka cesarzy Zenona i Anastazjusza, która spotkała się ze sprzeciwem Rzymu i poskutkowała schizmą akacjańską (484-519)6. Papiestwo nie dążyło wtedy jednak do formalnej politycznej i terytorialnej niezależności od władzy cesarskiej, szczególnie że ta przejściowo zanikła w Italii po usunięciu cesarza Zachodu Romulusa Augustulusa przez germańskiego wodza Odoakra w 476 r. Powstałe nieco później na obszarze Italii państwo Ostrogotów uznawało tylko czysto symboliczną zwierzchność rezydującego w Konstantynopolu władcy.

W wyniku szeroko zakrojonego programu rekonkwisty realizowanego przez cesarza Justyniana Konstantynopol odzyskał jednak kontrolę nad częścią zajętych przez różne ludy germańskie obszarów na zachodzie. Do lat 50. VI w. udało się także spacyfikować Ostrogotów i odzyskać kontrolę nad całą Italią. W 568 (lub 569) r. Półwysep Apeniński najechała jednak kolejna fala barbarzyńców w postaci ludu Longobardów, zajmując znaczną część Italii i tworząc tam własną państwowość. Środkowa część półwyspu wraz z Rzymem i Rawenną oraz niektóre odizolowane obszary w innych częściach Italii pozostały pod kontrolą cesarza. By przeciwstawić się longobardzkiemu naporowi, bizantyńskie posiadłości w Italii poddane zostały silnej militaryzacji, czego przejawem było powstanie scentralizowanej struktury administracyjnej w postaci egzarchatu Rawenny i podlegających mu dukatów. Osobnego duksa wyznaczono także dla Rzymu. Silna pozycja przysyłanej ze wschodu, zazwyczaj greckojęzycznej kadry urzędniczo-wojskowej

Zob. J. Gordziałkowski, Historia Państwa Kościelnego, Kraków 2007, s. 47; B. Zientara, Świt narodów europejskich. Powstawanie świadomości narodowej na obszarze Europy postkarolińskiej, wyd. 2, Warszawa 2017, s. 252-253. Na temat aparatu administracyjnego papiestwa zob. T.F.X. Noble, The Republic of St. Peter. The Birth of the Papal State 680-825, Philadelphia 1986, s. 212-255.

6 O relacjach między papiestwem a władzą cesarską w tym okresie zob. F. Dvornik, Bizancjum a prymat Rzymu, przeł. M. Radożycka, Warszawa 1985, s. 20-50; D.H. Miller, The Roman Revolution..., s. 79-87. 
skazywała papiestwo na polityczną marginalizację ${ }^{7}$. Władza cesarska traktowała biskupów Rzymu niekiedy z dużą dozą brutalności, czego najbardziej jaskrawym przykładem jest usunięcie z urzędu (653 r.) i okaleczenie Marcina I, który nie podporządkował się sformułowanemu w Konstantynopolu cesarskiemu zakazowi dyskusji na temat doktryny monoteletyzmu i potępił ją

Jednakże w VII w. zaczęły pojawiać się także tendencje korzystne dla procesu ewentualnej politycznej emancypacji papiestwa. Ogromne problemy, jakie Bizancjum przeżywało na wschodnich granicach (wyniszczający konflikt z sasanidzką Persją, a potem ekspansja arabska, która pozbawiła cesarstwo rozległych terytoriów i realnie zagroziła jego podstawom bytowym), sprawiały, że Italia jako region peryferyjny przestawała budzić większe zainteresowanie Konstantynopola. W latach 80. VII w. zmniejszono sumę pieniężną, którą papieże przekazywali zwyczajowo cesarzowi w momencie wyboru na Stolicę Piotrową, a sama elekcja zatwierdzana była już tylko przez egzarchę, a nie władcę. Nastąpił także wzrost zamożności papiestwa, kumulującego skrzętnie darowizny, głównie w postaci posiadłości ziemskich, i budującego tym samym pokaźną grupę klientelną, stając się powoli równorzędnym partnerem dla arystokracji wojskowej. Kadra administracyjno-wojskowa egzarchatu, za wyjątkiem samych egzarchów, zaczęła być w tym czasie rekrutowana spośród przedstawicieli ludności italskiej, lojalnej wobec Konstantynopola w sposób mocno ograniczony, co prowadziło do wzmocnienia nastrojów separatystycznych i propapieskich ${ }^{9}$. Wymownym świadectwem przemian był fakt, że cesarz Justynian II nie był w stanie na przełomie VII i VIII w. wymusić na papieżu Sergiuszu akceptacji decyzji tzw. Soboru in Trullo, a próba siłowego rozwiązania problemu zakończyła się zamordowaniem egzarchy przez stronników papieża. Wobec wzrostu realnej siły papiestwa cesarz zdecydował się zaproponować pokojowe porozumienie kolejnemu papieżowi - reprezentującemu linię polityczno-ideową Sergiusza Konstantynowi ${ }^{10}$.

Okresem przełomowym dla politycznej emancypacji papiestwa było panowanie cesarza Leona III $(717-741)^{11}$. Wzmocnił on nadszarpnięty wcześniej prestiż władzy

O reorganizacji administracyjnej bizantyńskich posiadłości w Italii w tym okresie zob. G. Ravegnani, I bizantini in Italia, Bologna 2004, s. 80-85; E. Zanini, Le Italie bizantine. Territorio, insediamenti ed economia nella provincia bizantina d'Italia (VI-VIII secolo), Bari 1998, s. 59-63. Na temat elit wojskowych Italii zob. F. Borri, Duces e magistri militum nell'Italia esarcale (VI-VIII secolo), „Reti Medievali Rivista" 2005, nr 2, s. 1-32.

$8 \quad$ F. Dvornik, Bizancjum a prymat..., s. 64-66.

9 P. Llewellyn, The Popes and the Constitution in the Eighth Century, "The English Historical Review” 1986, nr 101 (398), s. 42-50; P. Llewellyn, The Roman Church on the Outbreak of Iconoclasm, [w:] Iconoclasm, red. A. Bryer, J. Herrin, Birmingham 1975, s. 29-32; M. McCormick, Bizancjum z perspektywy Zachodu, [w:] Bizancjum ok. 500-1024, red. J. Shepard, przeł. K. Pachniak, J.S. Partyka, R. Piotrowski, Warszawa 2012, s. 401-404; D.H. Miller, The Roman Revolution..., s. 88-94; B. Zientara, Świt narodów..., s. 240.

10 F. Dvornik, Bizancjum a prymat..., s. 68-69.

11 Zob. F. Marazzi, Il conflitto fra Leone III Isaurico e il papato fra il 725 e il 733, e il 'definitivo' inizio del medioevo a Roma: un'ipotesi in discussione, „Papers of the British School at Rome” 1991, vol. 59, s. 231-257. 
bizantyńskiej i postanowił narzucić Stolicy Piotrowej swoją ścisłą dominację. W sytuacji gdy papiestwo cieszyło się już sporymi wpływami i dużym zapleczem społecznym, okazało się to jednak niemożliwe. Papież Grzegorz II uniemożliwił Konstantynopolowi wprowadzenie w życie niekorzystnych dla kurii rzymskiej zasad polityki fiskalnej. Niesnaski te zbiegły się w czasie z wybuchem w 726 r. wielkiego sporu religijnego dotyczącego kultu obrazów (sporu ikonoklastycznego). Cesarz próbował siłą narzucić Italii zakaz kultu świętych wizerunków, jednak spotkał się z kategoryczną kontrakcją. $\mathrm{Na}$ silający się w kolejnych latach konflikt doktrynalny w połączeniu ze wzmożoną presją longobardzką, znacznie nadwyrężającą siły egzarchy, sprawiły, że choć następcy Grzegorza II pełniący swe pontyfikaty w I połowie VIII w. nie wyłamywali się formalnie spod zwierzchności Konstantynopola (i chyba nie było to ich celem), to odgrywali już w praktyce samodzielną rolę polityczną ${ }^{12}$.

Wzmożenie agresji longobardzkiej dotyczyło nie tylko obszarów pod bezpośrednią kontrolą egzarchy, ale także Rzymu i Lacjum, pozostających pod kontrolą papieża. W szczególnie trudnej sytuacji znalazł się Stefan II, kiedy w 751 r. właściwy egzarchat został podbity przez króla longobardzkiego Aistulfa. Agresja władcy skierowała się wtedy bezpośrednio ku Rzymowi. Wobec całkowitej niezdolności Konstantynopola do interwencji na rzecz papiestwa doprowadziło to do sojuszu Stefana II z królem Franków Pepinem Małym, który potrzebował papieskiego wsparcia, by wzmocnić ideologiczne podstawy swojej władzy. W wyniku dwóch interwencji z lat 755-756 Pepin zajął i następnie przekazal papiestwu większą część dawnych terytoriów egzarchatu podbitych wcześniej przez Longobardów. W ten sposób powstało Państwo Kościelne, formalnie niezależne już od Bizancjum i opierające się na protekcji frankijskiej, choć wciąż zagrożone roszczeniami longobardzkimi ${ }^{13}$.

\section{GRANICE PAŃSTWA KOŚCIELNEGO W LATACH 756-774. PROBLEM PLENARIA IUSTITIAE}

Dokładne określenie obszaru, nad którym papież sprawował kontrolę przed 756 r., jest kwestią dość problematyczną. Biskup Rzymu i członkowie kurii posiadali niewątpliwie duże uprawnienia administracyjne na terenie samego miasta, a do papieża należały liczne patrymonia rozrzucone w różnych częściach Italii, głównie na Sycylii. Wieczne Miasto wraz z całym regionem Lacjum wchodziło jednak w skład ogólnoitalskiej

12 Teza Davida H. Millera, wedle której papiestwo dążyło do całkowitego zerwania z Bizancjum już na początku kryzysu ikonoklastycznego, nie wydaje się przekonywająca. Więcej racji ma Philip Daileader, który zauważa, że papiestwo (mimo konfliktów) wciąż szukało wsparcia w Konstantynopolu przeciw Longobardom i jednocześnie dbało o dobre stosunki z Frankami, por. P. Daileader, One Will, One Voice, and Equal Love: Papal Elections and the „Liber Pontificalis” in the Early Middle Ages, „Archivum Historiae Pontificiae" 1993, vol. 31, s. 22-24; D.H. Miller, The Roman Revolution..., s. 108-112.

13 Zob. np. B. Kumor, Historia Kościota, t. 2: Wczesne średniowiecze chrześcijańskie, Lublin 2001, s. 34-35; R. McKitterick, Królestwa Karolingów. Wtadza, konflikty, kultura - 751-987, przeł. B. Hlebowicz, M. Wilk, Warszawa 2011, s. 64-69. 
bizantyńskiej jednostki administracyjnej, jaką był egzarchat Rawenny. Dodatkowo w części terytorium egzarchatu wydzielono mniejsze jednostki administracyjne w randze dukatów (ducatus), zarządzane przez urzędników o tytule duksa. Za pontyfikatu Grzegorza Wielkiego powstał także dukat rzymski, obejmujący Lacjum, tzw. rzymską Toskanię i tzw. rzymską Kampanię. Sytuacja ta rodziła konflikty kompetencyjne między administracją papieską a cywilno-wojskową. W okresie pogorszenia się relacji papiesko-bizantyńskich w wyniku sporu ikonoklastycznego, któremu towarzyszyło wzmożenie longobardzkiej presji militarnej, pozycja duksa Rzymu uległa jednak osłabieniu, choć sam urząd funkcjonował aż do lat 80 . VIII w. już w pełni niezależnej od Bizancjum Republice św. Piotra ${ }^{14}$.

Niejasna sytuacja polityczna papiestwa uległa zmianie w wyniku podboju właściwego egzarchatu wraz z Rawenną przez króla longobardzkiego Aistulfa w latach 50. VIII w. i interwencji frankijskich z 755 i 756 r. Frankowie, pokonując Longobardów, obronili Rzym przed podbojem, a oprócz tego przekazali papieżowi Stefanowi II (kontrolującemu już terytorium dukatu rzymskiego) dużą część obszarów uprzednio zdobytych przez Longobardów. Wedle biogramu Stefana II w Liber Pontificalis papież otrzymał wtedy od Pepina Małego następujące miejscowości i warownie: Rawenna, Rimini, Pesaro, Conca, Fano, Cesena, Senigallia, Iesi, Forlimpopoli, Forli, Sussubium, Montefeltero, Arcevia, Mons Lucati, Serra, San Marino, Vobio, Urbino, Cagli, Lucioli, Gubbio, Commacchio i Narni ${ }^{15}$. Obszar ten stanowił zwarte terytorium, opierające się o Adriatyk na wschodzie i Apeniny na zachodzie, składające się z właściwego egzarchatu (terytoriów bezpośrednio podlegających Rawennie bez pośrednictwa dukatów) oraz większej części dukatu Pentapolis. Nie obejmował jednak dawnego bizantyńskiego dukatu Ferrary na północy oraz części dukatu Pentapolis (Osimo i Ankona) na południu. Wyjątek od tej charakterystyki stanowiło Narni, które znajdowało się w oddaleniu od wyżej wymienionych miejscowości (tuż nad granicą dukatu rzymskiego) i należało wcześniej do stosunkowo niezależnego od królów longobardzkiego księstwa Spoleto.

Co ciekawe, spis nie zawiera informacji o ewentualnym przekazaniu papiestwu dukatu Perugii, choć bez tego zabiegu nie istniałoby lądowe połączenie między dukatem rzymskim a nowymi nabytkami papiestwa. Przynależność miasta do posiadłości papieskich potwierdza późniejszy dokument Pactum Ludovicianum we fragmencie dotyczącym dawnych darowizn królów frankijskich w centralnej Italiii ${ }^{16}$. Jednocześnie Perugia nie została wymieniona w Liber Pontificalis wśród nowych terytoriów przekazanych papiestwu przez Karola Wielkiego w 774 r. Wszystko to może sugerować (choć nie musi), że dukat Perugii został podporządkowany papieżowi wcześniej - albo od razu po upadku władzy bizantyńskiej w Rawennie, albo na mocy porozumienia z Frankami z $756 \mathrm{r}$.

14 T.F.X. Noble, The Republic of St. Peter.., s. 1-11, 234-235; G. Ravegnani, I bizantini in Italia..., s. 82-83; E. Zanini, Le Italie byzantine..., s. 61.

15 LP, XCIV, 47, s. 263.

16 Pactum, s. 353. 
Terytorium, o którym mowa w Liber Pontificalis, zostało przekazane „św. Piotrowi" - Stefanowi II i jego następcom - na mocy wieczystej darowizny frankijskiego króla. Klucze do bram miejskich (symboliczną rękojmię wierności) odbierał w poszczególnych miejscowościach wysłannik Pepina - opat Fulrad, który dopiero potem przekazał je papieżowi wraz z dostarczonymi przez wspólnoty miejskie zakładnikami, co przypieczętowało przejście dawnych obszarów egzarchatu pod zwierzchnictwo Rzymu. Sposób, w jaki to się odbyło, można interpretować jako zamierzone zademonstrowanie przez Pepina swojej przewagi politycznej nad papiestwem. Nie należy jednak traktować tego aktu jako wyrazu sformalizowanej zależności, a raczej jako zabieg propagandowy, mający na celu podniesienie prestiżu króla ${ }^{17}$.

Kiedy pod koniec 756 r. zmarł Aistulf, rozgorzała walka o tron longobardzki między toskańskim księciem Dezyderiuszem a bratem Aistulfa - Ratchisem. W tym konflikcie papież zdecydował się stanąć po stronie Toskańczyka, który zwracając się do biskupa Rzymu o pomoc, zaoferował mu zwrot części innych miast, należących niegdyś do egzarchatu, ale których nie przekazał Aistulf. Stefan II wspomógł militarnie Dezyderiusza, któremu udało się ostatecznie pokonać przeciwnika i objąć tron. Wedle $L i$ ber Pontificalis papież za pośrednictwem posła miał przejąć wtedy władzę nad Faenzą, warownią Tiberiacum (w tekście autor podał także zamienną nazwę - Gabellum) oraz dukatem Ferrary ${ }^{18}$. $Z$ treścią przekazu stworzonego przez papieskiego biografa nie pokrywają się jednak informacje zawarte w kierowanych do Pepina listach kolejnego papieża - Pawła I, umieszczonych w zbiorze Codex Carolinus. Paweł I, pisząc o obszarach, których obiecał się zrzec Dezyderiusz, wymienił bowiem następujące miejscowości: Faenza, Imola, Ferrara, Osimo, Ankona, Bolonia i Umana ${ }^{19}$. Wykaz ten nie w pełni pokrywa się więc z informacjami znajdującymi się w Liber Pontificalis. Co więcej, z analizy korespondencji papieskiej jasno wynika, że miejscowości te, choć obiecane przez Dezyderiusza Stefanowi, nigdy nie zostały przekazane przez Longobardów papiestwu i stały się przyczyną zabiegów Pawła I o ponowną interwencję frankijską, która miałaby zmusić Dezyderiusza do respektowania układów i szanowania integralności terytorialnej Państwa Kościelnego ${ }^{20}$.

Sporny obszar w literaturze określany jest zbiorczo jako terytoria tzw. plenaria iustitiae. Tego terminu używał w odniesieniu do nich Paweł I w swoich listach. Błędem jest

17 Na temat formalnego wymiaru stosunków między Państwem Kościelnym a jego frankijskimi protektorami zob. T.F.X. Noble, The Republic of St. Peter..., s. 262-275.

18 LP, XCIV, 48-51, s. 263-264. Autorzy polskiego przekładu uznali, że pojawiające się w łacińskim tekście określenie Gabellum dotyczy zupełnie innej miejscowości, noszącej obecnie nazwę Gavello (choć w tłumaczeniu pojawiającej się jako Cavello) i znajdującej się w Wenecji Euganejskiej. Użyte w oryginale sformułowanie lacińskie (Tiberiaco seu Gabellum) wskazuje jednak, że chodzi raczej o zamiennik nazwy Tiberiacum niż o miejscowość w Wenecji Euganejskiej, która leżała w pewnym oddaleniu od reszty omawianych ziem.

19 CC, XI, s. 506.

20 Zob. J.T. Hallenbeck, Instances of Peace in Eighth-century Lombard-Papal Relations, „Archivum Historiae Pontificiae" 1980, vol. 18, s. 49-52; D.H. Miller, Papal-Lombard Relations during the Pontificate of Pope Paul I: The Attainment of an Equilibrium of Power in Italy, 756-767, „The Catholic Historical Review" 1969, vol. 55, nr 3, s. 358-376. 
jednak charakteryzowanie ich jako obszarów egzarchatu podbitych jeszcze przez króla Liutpranda $(712-744)^{21}$. Owszem, władca ten prowadził wobec egzarchatu agresywną politykę i uzyskał jego kosztem pewne nabytki terytorialne, nie da się jednak wykazać, że opanował na stałe akurat te miejscowości. Na liście jego zdobyczy pojawiły się co prawda obecne w korespondencji Pawła I Ankona i Osimo, jednak w wyniku układu zawartego z papieżem Zachariaszem zrzekł się on ich dość szybko ${ }^{22}$. Miejscowości, których dotyczyło porozumienie między Stefanem II i Dezyderiuszem, najprawdopodobniej zostały utracone przez egzarchat za panowania Aistulfa, na początku lat 50. VIII w., w czasie kiedy upadła sama Rawenna. W wyniku braku odpowiednich świadectw źródłowych nie da się szczegółowo odtworzyć przebiegu longobardzkiej ekspansji w tym okresie. W związku z tym należy ograniczyć się do ogólnego stwierdzenia o przejęciu przez królestwo ze stolicą w Pawii kontroli nad właściwym egzarchatem.

Fakt, że wykazy miejscowości zawarte w Codex Carolinus i Liber Pontificalis nie pokrywają się w całości, powinien wprawiać w konsternację, choć o dziwo na ten problem nie zwrócili uwagi historycy szczegółowo zajmujący się relacjami papiesko-longobardzkimi w tym okresie. Wydaje się, że dokonując odpowiedniego zestawienia przekazów, można je jednak pogodzić, przynajmniej w kwestii obszarów położonych na północy. Autor biogramu Stefana II w Liber Pontificalis pisał bowiem o przejęciu przez papiestwo kontroli nad Faenzą i warownią Tiberiacum wymienionymi osobno oraz dukatem Ferrary. Natomiast część wymienionych przez Pawła I miejscowości (Imola, Ferrara, Bolonia) znajduje się w regionie Emilii, w którym leżał dukat Ferrary, i niewątpliwie wchodziły one w skład tej dawnej bizantyńskiej jednostki administracyjnej. Wyjątkiem mogły być tutaj Faenza i Tiberiacum, które w Liber Pontificalis wymienione zostały osobno, choć też leżą w Emilii, co wskazuje, że nie wchodziły w skład dukatu, ale wcześniej bezpośrednio podlegały Rawennie. Nieuwzględnienie Tiberiacum w liście z Codex Carolinus wynikało najprawdopodobniej z faktu, że warownia ta leżała tak blisko Faenzy, iż potraktowano ją w tym wypadku jako podlegającą jej. Paweł I, pisząc do Pepina, prawdopodobnie uznał, że najlepszym sposobem naszkicowania problemu będzie szczegółowe wzmiankowanie nazw miejscowości będących przedmiotem sporu. Pojęcie dukatu Ferrary mogło być bowiem dla Franka zbyt ogólne, co nie pomogłoby przy rozwiązaniu sporu. Poza tym w skład tej jednostki administracyjnej nie wchodziła najprawdopodobniej Faenza, więc i tak należałoby wymienić ją osobno. Reasumując, można założyć, że zarówno autor biogramu Stefana II, jak i Paweł I, pisząc o dukacie Ferrary bądź wyszczególniając miejscowości, mieli na myśli dokładnie ten sam obszar mimo pewnych pozornych rozbieżności. Obu piszącym przyświecały inne cele. Paweł I chciał precyzyjnie przedstawić królowi Franków, do których miast rości sobie pretensje, i sprowokować jego interwencję. Autor Liber Pontificalis miał natomiast przed sobą zadanie czysto kronikarskie, polegające na upamiętnieniu dokonań

21 Tak określili je zarówno Jan T. Hallenbeck, jak i David H. Miller, nie podając jednak żadnego głębszego uzasadnienia, zob. J.T. Hallenbeck, Instances of Peace..., s. 49; D.H. Miller, Papal-Lombard Relations..., s. 364 .

22 Zob. LP, XCIII, 9, s. 239. 
Stefana II. Mógł więc posługiwać się terminami bardziej ogólnymi, jak właśnie dukat Ferrary, szczególnie że w kręgach italskich były one zdecydowanie lepiej rozumiane niż w państwie Franków.

W listach Pawła I pojawiają się też informacje dotyczące przekazania papiestwu przez Longobardów Ankony, Osimo i Umany, których nie wymienia autor Liber Pontificalis $^{23}$. Miasta te stanowiły południowy skraj dukatu Pentapolis, który został w większości przekazany papiestwu jeszcze za czasów Aistulfa, jednak bez tych miejscowości. Znaczna odległość geograficzna od dukatu Ferrary (oddzielenie ziemiami właściwego egzarchatu) i udokumentowana odrębność administracyjna nie pozwalają w żaden sposób łączyć pominięcia tych dwóch miast $\mathrm{z}$ omówionym wyżej zabiegiem uogólniającym zastosowanym przez papieskiego biografa.

$\mathrm{Z}$ pewną dozą ostrożności można założyć, że terytorium to rzeczywiście mogło stanowić przedmiot układów między Stefanem II a Dezyderiuszem. Aistulf zapewne nalegał na zatrzymanie Ankony podczas negocjacji z Pepinem i papieżem, ponieważ była ona kluczowym w tym regionie portem, ważnym dla longobardzkiej gospodarki ${ }^{24}$. Miasta tego nie ma na liście miejscowości przekazanych papiestwu przez Aistulfa, więc na pewno udało mu się je zatrzymać. Dezyderiusz natomiast, dążąc w pierwszej kolejności do uzyskania korony, w zamian za pomoc najprawdopodobniej obiecał Stefanowi przekazanie Ankony wraz z pobliskimi Osimo i Umaną, czego jednak nie miał zamiaru dotrzymywać. Przekaz Codex Carolinus wydaje się w tym aspekcie wiarygodny, ponieważ Paweł I raczej nie starałby się oszukiwać swojego frankijskiego protektora, przedstawiając mu nieuzasadnione roszczenia względem Longobardów. Jedynym wytłumaczeniem dla pominięcia informacji o scedowaniu Ankony, Osimo i Umany w Liber Pontificalis jest natomiast chyba tylko nieuwaga kronikarza, który zwyczajnie zapomniał je wymienić. Trudno bowiem posądzać go o celowe ukrywanie faktów, ponieważ w czasie, kiedy biogram był tworzony, trwał już spór o terytoria plenaria iustitiae i propapieski historiograf raczej starałby się uwypuklić prawa Stolicy Piotrowej, niż je umniejszać.

Spór papiesko-longobardzki o plenaria iustitiae ciągnął się aż do upadku longobardzkiego królestwa w 774 r. $^{25}$ Początkowo Paweł I domagał się od Pepina Małego pomocy zbrojnej, by wyegzekwować swoje prawa ${ }^{26}$. Obrazu tego nie mógł zburzyć nawet zaskakujący list, w którym papież zapewnia króla frankijskiego o przyjaźni z Dezyderiuszem i rzekomej gotowości króla do oddania Imoli ${ }^{27}$. Napisany on został pod naciskiem władcy longobardzkiego, który przejściowo zajął Rzym, co papież przyznał w dalszej korespondencji ${ }^{28}$. Widząc jednak, że Frankowie nie są zainteresowani kolejną

23 CC, XI, s. 506.

O znaczeniu gospodarczym portów adriatyckich dla Longobardów zob. O.P. Бородин, Равеннский Экзархат. Византийиы в Италии, Санкт-Петербург 2001, s. 114.

Zob. J.T. Hallenbeck, Pavia and Rome: The Lombard Monarchy and the Papacy in the Eighth Century, Philadelphia 1982, s. 91-112, 140-156.

26

CC, XIV, s. 512.

27 CC, XVI, s. 513.

28

CC, XVII, s. 517. 
interwencją w Italii, biskup Rzymu zdecydował się przystać na ich propozycje pokojowego rozwiązania sporu z Longobardami. Od 760 r. przy udziale frankijskich mediatorów toczyły się rozmowy w sprawie wytyczenia granicy. Papież najprawdopodobniej zrezygnował z plenaria iustitiae w zamian za przekazanie mu jakichś nieokreślonych obszarów, które miały stanowić własność św. Piotra (omnes iustitias beati Petri) ${ }^{29}$. David H. Miller twierdził, że chodzić mogło o pewne terytoria, których dotyczył jeszcze układ z Aistulfem, ale których z jakichś powodów nie przekazano papiestwu. Wskazywać na to może fakt, że w trakcie negocjacji obecni byli przedstawiciele miast Pentapolis, które w większości miało zostać przekazane papiestwu w $756 \mathrm{r} .{ }^{30}$ Wydaje się, że terytoria te nie znajdowały się pod kontrolą papiestwa, nie dlatego, że Aistulf nie dotrzymał obietnic, ale dlatego, że zostały przejęte przez Dezyderiusza w toku agresywnych działań prowadzonych przeciw Rzymowi tuż przed 760 r. Król Longobardów, korzystając z frankijskiej bierności militarnej, dość długo ociągał się z realizacją swojej kolejnej obietnicy, jednak w niejasnych okolicznościach zdecydował się poczynić pewne ustępstwa w 765 r. Co zaskakujące, z listów Pawła wynika, że papiestwu przekazane zostać miały nie obszary plenaria iustitiae ani miasta, których dotyczył układ z Aistulfem, ale zupełnie inne terytoria. Chodziło tutaj o część Toskanii (nie wiadomo, czy rzymskiej, czy longobardzkiej), a także o jakieś ziemie w księstwach Spoleto i Benewentu, co sugerowałoby, że Dezyderiusz musiał zmusić książęta do ustępstw. Papież pisał jednak, że wciąż stara się o uzyskanie kolejnych nabytków ${ }^{31}$. Niestety w źródłach istnieje kilkuletnia luka dotycząca ewentualnej kontynuacji tych wysiłków, która kończy się dopiero w $771 \mathrm{r}$.

Bardzo prawdopodobne, że papież w latach 60 . i na początku lat 70 . VIII w. miał też pewne problemy z narzuceniem swojego autorytetu w samej Rawennie. Świadczy o tym chociażby list do Pepina Małego, w którym Paweł I prosi o mediację między nim a zamieszkującymi dawną stolicę egzarchatu Grekami ${ }^{32}$. Z kolei już za pontyfikatu Hadriana I nieposłuszny arcybiskup Rawenny zdecydował się zgładzić wbrew woli papieża niejakiego Pawła Afiartę ${ }^{33}$. Trudno stwierdzić, czy informacje te świadczą o nieuznawaniu cywilnej władzy papieża w mieście, ponieważ są zbyt niejednoznaczne. Biorąc jednak pod uwagę, jakich problemów nastręczał Hadrianowi arcybiskup Leon po 774 r., jest to dość prawdopodobne.

Intrygującym faktem jest, że autor biografii Pawła I nie napisał zupełnie nic na temat polityki zagranicznej tego papieża, która była przecież bardzo intensywna, czego dowodzą listy z Codex Carolinus. Można wysunąć pewną hipotezę, która wyjaśniałaby taki stan rzeczy. Biogram mógł bowiem powstać około 771 r., za pontyfikatu Stefana III, kiedy relacje papiesko-longobardzkie na krótko poprawiły się. Ówczesny papież w porozumieniu z królem Dezyderiuszem doprowadził nawet do usunięcia kurialnego

\footnotetext{
29 CC, XIX, XXXIV, s. 520, 541.

30 Zob. D.H. Miller, Papal-Lombard Relations..., s. 372.

31 CC, XXXVII, s. 549.

32 CC, XXXVIII, s. 551.

33 LP, XCVII, 11-15, 17, s. 5-7, 8.
} 
urzędnika - prymiceriusza Krzysztofa, który próbował ponownie podnosić problem plenaria iustitiae lub innych spornych terenów ${ }^{34}$. Kwestia terytorialna odżyła jednak niedługo potem (w 772 r.), kiedy na Stolicę Piotrową wstąpił Hadrian I. Papież ten nastawiony był dość konfrontacyjnie i wykorzystując konflikty między Dezyderiuszem a nowym władcą frankijskim Karolem Wielkim, doprowadził do ponownej frankijskiej interwencji, która ostatecznie zlikwidowała zagrożenie longobardzkie.

\section{GRANICE PAŃSTWA KOŚCIELNEGO PO 774 R. POROZUMIENIE PAPIESKO-FRANKIJSKIE I JEGO REALIZACJA}

W 772 r. papież Hadrian I zdecydował się ponownie upomnieć o przekazanie spornych terytoriów, odmawiając Dezyderiuszowi odnowy układu przyjaźni zawartego ledwie rok wcześniej przez Stefana III. Zbiegło się to w czasie z pogorszeniem się relacji frankijskolongobardzkich. Dezyderiusz sprawował bowiem ówcześnie kontrolę nad wygnanymi synami Karlomana, zmarłego brata nowego króla Franków - Karola Wielkiego. Rezydujący w Pawii władca próbował w tym czasie upominać się o należny jego wnukom spadek po ojcu w postaci części ziem frankijskich, co groziło destabilizacją władzy Karola. W tym celu król Longobardów próbował bezskutecznie zmusić papieża do udzielenia im namaszczenia, zajmując część jego terytoriów i grożąc wyprawą na Rzym. Zarówno Hadrian, jak i Karol poczuli się poważnie zagrożeni, a w 773 r. na prośbę papieża król Franków zdecydował się przekroczyć Alpy i stanąć do konfrontacji z Longobardami ${ }^{35}$.

Po pokonaniu części sił Dezyderiusza w 773 r. (choć oblężenie Pawii zakończyło się dopiero w połowie $774 \mathrm{r}$.) i zlikwidowaniu niezależnego państwa longobardzkiego, które przeszło teraz pod kontrolę Franków, Karol zdecydował się Wielkanoc 774 r. spędzić w Rzymie. Tam też odnowił darowiznę swego ojca, Pepina Małego, jednocześnie przekazując papiestwu nowe rozległe terytoria. Na podstawie treści biogramu Hadriana I w Liber Pontificalis można pokusić się o rekonstrukcję granic tych obszarów. Kronikarz wzmiankuje mianowicie, że papiestwo uzyskało następujące miejscowości: Luni i Suri w Ligurii, a także Berceto (z górą Bardone), Parmę, Reggio, Mantuę i Monselice w Regionie Emilii. Linia łącząca te miasta tworzyłaby zwartą granicę ciągnącą się od pogranicza dawnego egzarchatu i dukatu Wenecji do wybrzeża liguryjskiego, pozostawiając po stronie papieskiej całą Emilię i Toskanię. Wydaje się, że treść źródła należy odczytywać właśnie jako próbę zarysowania granicy obejmującej szersze terytoria, ponieważ dziwnym zabiegiem byłoby przekazanie Republice św. Piotra samych miast, znajdujących się w pewnym oddaleniu od pozostałych posiadłości rzymskich,

Zob. J.T. Hallenbeck, Pope Stephen III. Why Was He Elected?, „Archivum Historiae Pontificiae” 1974, vol. 12, s. 287-299.

35 Zob. W. Fałkowski, Wielki Król. Ideologiczne podstawy wtadzy Karola Wielkiego, Warszawa 2011, s. 107-110; J.T. Hallenbeck, Paul Afiarta and the Papacy: An Analysis of Policy in Eighth-Century Rome, „Archivum Historiae Pontificiae” 1974, vol. 12, s. 33-54; tenże, Pavia and Rome..., s. 97-170; D.S. Sefton, Pope Hadrian I and the Fall of the Kingdom of the Lombards, „The Catholic Historical Review" 1979, vol. 65, nr 2, s. 206-220. 
nie ofiarowując papieżowi jednocześnie dawnej longobardzkiej części Toskanii. Wedle Liber Pontificalis papież miał uzyskać wtedy także Korsykę, prowincję Wenetów (zapewne chodziło o dukat Wenecji), Istrię oraz longobardzkie księstwa Spoleto i Benewentu. Potwierdzono też papieskie prawa do ziem właściwego egzarchatu ${ }^{36}$.

Fragment biogramu Hadriana I w Liber Pontificalis dotyczący wydarzeń po 774 r. nie dostarcza jakichkolwiek informacji na temat stosunków papiestwa z Frankami ani realizacji obietnic terytorialnych. Struktura obu części biografii jest zresztą tak odmienna (część do 774 r. to szczegółowy opis wydarzeń politycznych, a część dotycząca dziejów pontyfikatu w latach 774-795 stanowi tylko rozbudowany do granic możliwości wykaz działalności fundatorskiej papieża), że pozwala ona wysnuć wniosek, iż pisana była w dużym odstępie czasu, być może przez dwie różne osoby ${ }^{37}$.

Informacji na temat realizacji porozumienia z 774 r. dostarczają jednak listy Hadriana do Karola Wielkiego zamieszczone w zbiorze Codex Carolinus. Wynika z nich, że papież nie był w stanie wyegzekwować swoich praw do nowo nabytych terytoriów. Świadczą o tym kierowane do Karola Wielkiego skargi dotyczące longobardzkiego duksa Reginalda, który sprawował rzeczywistą kontrolę nad świeżo przyznaną Rzymowi częścią Toskanii i uniemożliwiał wprowadzenie tam papieskiej administracji ${ }^{38}$. O tym, że papież nie sprawował realnej zwierzchności nad Benewentem i Spoleto, świadczą listy, w których informował Karola, że władcy obu księstw spiskują przeciw papieżowi w porozumieniu z Bizantyńczykami i gotowi są do przeprowadzenia akcji militarnej ${ }^{39}$. Świadectwem niemożności objęcia przez papieża faktycznej władzy nad Istrią jest natomiast informacja o wygnaniu stamtąd propapieskiego biskupa przez Greków ${ }^{40}$.

Co dość zaskakujące, papież nie tylko nie był w stanie wyegzekwować praw do nowo przyznanych terytoriów, ale także do obszaru właściwego egzarchatu, przyznanego Stolicy Piotrowej jeszcze przez Pepina Małego. Terytorium to, jak wynika ze skarg Hadriana, znajdowało się pod silnym wpływem arcybiskupa Rawenny Leona, który uniemożliwiał przedstawicielom lokalnych elit kontakty z Rzymem i ostro występował przeciw papieskim wysłannikom. Oprócz właściwego egzarchatu Leon sprawował realną władzę także nad dukatem Ferrary, czyli częścią plenaria iustitiae, o które papiestwo toczyło wcześniej spór z Longobardami ${ }^{41}$. Wynika z tego, że Hadrian uznawał plenaria iustitiae za element porozumienia z 774 r., choć informacja o tym nie pojawia się w $L i$ ber Pontificalis wprost. Określenie „cały egzarchat Rawenny” jest w tym wypadku problematyczne w interpretacji i trudno stwierdzić, czy dotyczyło tylko części egzarchatu bezpośrednio podlegającej Rawennie, czy także obu dukatów sąsiadujących z nią od południa i północy. Szersze znaczenie wydaje się jednak bliższe prawdy - papież chyba bezpodstawnie nie zgłaszałby bowiem roszczeń do dukatu Ferrary i miast leżących

\footnotetext{
LP, XCVII, 42, s. 17.

T.F.X. Noble, The Republic of St. Peter..., s. 141.

CC, LVIII, s. 583-584.

CC, LVII, s. 582-583.

CC, LXIII, s. 590.

CC, XLIX, LV, s. 568-569, 579-580.
} 
w dukacie Pentapolis. Co ciekawe, wśród wymienianych miejscowości należących do tego drugiego dukatu, nad którymi kontroli nie mógł przejąć Hadrian, nie ma Ankony. Sugerować to może, że ten peryferyjnie położony port nie poddał się wpływom Leona i przyjął papieskie zwierzchnictwo. W ten sposób papież uzyskać mógł władzę przynajmniej w skrawku plenaria iustitiae. Z zamieszczonych w Codex Carolinus listów wiadomo także, że Leon blokował ponadto komunikację papiestwa z Wenecją ${ }^{42}$.

Przyczyny niemożności objęcia przez papieża realnej władzy nad tymi terytoriami nie były jednolite. W przypadku Wenecji było to praktycznie niemożliwe nie tyle z powodu przeszkód stawianych przez arcybiskupa Rawenny, ale przede wszystkim dlatego, że region ten nie został podbity przez Franków i od dłuższego czasu pozostawał niezależny, posiadając własnego dożę, uznającego tylko formalną zwierzchność Bizancjum. Karol Wielki, przyznając go papieżowi w Wielkanoc 774 r., ofiarował mu w rzeczywistości coś, czego sam nie posiadał. Podobnie było w przypadku longobardzkich księstw Spoleto i Benewentu, które nie padty ofiarą frankijskiej agresji i choć uznały lenną zależność od Franków (w przypadku Benewentu tylko przejściowo), to ich książęta nie poczuwali się do podległości papieżowi. Silna pozycja arcybiskupa Leona uniemożliwiła Hadrianowi wyegzekwowanie swych praw do właściwego egzarchatu i dukatów Ferrary i Pentapolis. Jeszcze inaczej sprawy miały się w przypadku Toskanii oraz Istrii, gdzie papieskie wpływy rugowane były przez Longobardów bądź Greków. Dość przekonywająca (przynajmniej w części) wydaje się teza Thomasa F. X. Noble’a, który uważa, że król Franków w 774 r. był gotowy przekazać wymienione obszary papiestwu. Autor nie precyzuje jednak niestety, czy chodzi mu o wszystkie terytoria wymienione w Liber Pontificalis, czy tylko o te (jak Toskania czy egzarchat), którymi Karol Wielki mógł realnie dysponować. W każdym razie, trudności, z jakimi spotkał się król Franków, próbując ustabilizować w następnych latach sytuację w świeżo podbitym państwie Longobardów (Karol przyjął tytuł króla Longobardów, jednak zaraz potem zetknął się z dość silną opozycją w postaci chociażby margrabiego Rodgauda, który w 776 r. wszczął bunt), sprawiły, że zdecydował się on nie okrawać go terytorialnie, by nie budzić niezadowolenia miejscowych elit i zapewnić spokój ${ }^{43}$.

Hadrian, widząc, że wyegzekwowanie praw papiestwa napotyka olbrzymie problemy, na przełomie lat 70. i 80. VIII w. postanowił ograniczyć swoje roszczenia. W listach z tego okresu papież prosił już tylko o interwencję w celu przekazania papiestwu patrymoniów sabińskich, znajdujących się na pograniczu Państwa Kościelnego i księstwa Spoleto $^{44}$. Należy zwrócić uwagę, że w kontekście Sabiny użycie terminu patrymonium może oznaczać, iż biskupowi Rzymu nie chodziło w tym momencie o pełne podporządkowanie całości tego obszaru, ale jedynie o przyznanie mu prawa do leżących w nim posiadłości, z których papiestwo uzyskiwało niegdyś dochód. Stoi to w pewnej sprzeczności z tekstem Pactum Ludovicianum, w którym w kontekście Sabiny nie pojawia się określenie patrymonium, a terytorium. Papież stracił także na rzecz księstw Benewentu

\footnotetext{
42 CC, LIV, s. 576.

43 T.F.X. Noble, The Republic of St. Peter.., s. 144-145.

44 CC, LXVIII, LXIX, LXX, LXXI, LXXII, s. 598-602.
} 
Terracinę w Kampanii, prosząc bezskutecznie Karola o interwencję w tej sprawie ${ }^{45}$. W 779 r. Hadrian spróbował nawet samodzielnie odbić to miasto zbrojnie, jednak jego wojska zostały odparte przez Benewentańczyków wspieranych przez Bizancjum. Informacja o utracie Terraciny jest szczególnie intrygująca w kontekście wymienionych w dokumencie Pactum Ludovicianum leżących w Kampanii darowizn (sama Terracina się tam nie pojawia), leżących albo na południe, albo na północny wschód od tej miejscowości. Osobne poświadczenie przekazania papieżowi miejscowości w rzymskiej Kampanii (która przecież stanowiła dawniej część dukatu rzymskiego, wymienionego w Pactum oddzielnie) sugeruje, że cały ten obszar został utracony na rzecz Benewentu, a dotyczące go szczegółowe zapisy są świadectwem papieskich zabiegów o odzyskanie go.

Jak twierdzi Thomas Noble, Karol Wielki prawdopodobnie chciał w jakiś sposób zrekompensować papiestwu niespełnione obietnice z $774 \mathrm{r}^{46}$ Świadectwem tego jest dokument Pactum Ludovicianum, w którym następca Karola Ludwik Pobożny potwierdził w 817 r. darowizny jego przodków papieżowi Paschalisowi I. Co prawda w przypadku większości z wymienionych obszarów użyto tylko ogólnych stwierdzeń niepozwalających umiejscowić darowizny podczas panowania konkretnego władcy. Niekiedy jednak pojawiają się bardziej precyzyjne określenia. Dotyczy to po pierwsze terytorium Sabiny, które wraz z Rieti miało według dokumentu zostać przekazane Hadrianowi przez Karola. Po drugie dochodów z longobardzkiej części Toskanii i księstwa Spoleto, które przekazywane miały być do papieskiego skarbu także na mocy porozumienia Karola z Hadrianem ${ }^{47}$.

W dokumencie potwierdzone zostały także inne darowizny. Należały do nich dukat rzymski, rzymska Toskania, będące pod rzeczywistą kontrolą papieską, część Kampanii (z miastami Segni, Anagni, Ferentino, Alatri, Patrica, Frosinone i Tivoli), właściwy egzarchat wraz z dukatami Ferrary, Pentapolis, a także południowa część longobardzkiej Toskanii (z miastami Citta di Castello, Orvieto, Bagnorea, Farentum, Viterbo, Orchia, Marta, Toscanella, Sovana, Populonia, Grosseto $)^{48}$. Thomas Noble uważa, że wymienione potwierdzenia i darowizny można umiejscowić w 781 r., podobnie jak nadanie Sabiny i dochodów z Toskanii i Spoleto. Przemawiać za taką tezą mogą różne fakty. W przypadku Kampanii nawiązanie sojuszu frankijsko-bizantyńskiego w 781 r. pozostawiało Benewent w izolacji i mogło zmusić jego władcę Arechisa do przekazania papieżowi spornych terytoriów. Z kolei o nadaniu w tym roku Sabiny mogą świadczyć informacje zawarte w listach z Codex Carolinus $^{49}$. Przede wszystkim jednak w $781 \mathrm{r}$. Karol przybył do Rzymu, by papież ochrzcił jego syna Pepina, który został zaraz potem koronowany na króla Longobardów. Był to ze strony króla Franków ukłon w stronę elit longobardzkich i w związku z tym nie mógł wzbudzić zadowolenia papieża. Prawdopodobnie, by załagodzić ewentualny konflikt, Karol zdecydował się poczynić na rzecz Państwa Kościelnego koncesje terytorialne, obejmujące wymienione wyżej obszary

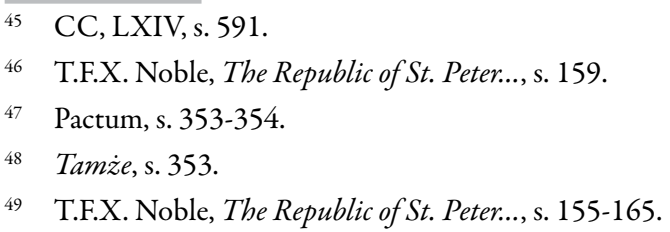


lub - w przypadku terytoriów realnie pozostających pod władzą papieską - potwierdzić rzymskie prawa do nich ${ }^{50}$.

W 787 r. (co potwierdzają informacje zawarte w niektórych rocznikach frankijskich) papież po wyprawie zbrojnej Karola na Benewent mógł natomiast uzyskać dalszy fragment Kampanii (z miastami Sora, Arce, Aquino, Arpino, Teano i Kapua), a także patrymonia w Benewencie i Salerno. Nieprawdopodobne jest natomiast, by Hadrianowi udało się uzyskać patrymonia w kontrolowanych przez Bizancjum Neapolu i Kalabrii $^{51}$. Wydaje się, że w Pactum Ludovicianum znalazły się one tylko jako wyraz hipotetycznych darowizn, które miałyby miejsce w wypadku zajęcia tych obszarów przez Franków. Również zdobycze w Kampanii okazały się nietrwałe, ponieważ następca Arechisa Grimoald bardzo szybko pozbawił papieża kontroli nad nimi ${ }^{52}$.

Pactum Ludovicianum zawiera także informacje o ofiarowaniu papieżowi Korsyki, Sardynii i Sycylii ${ }^{53}$. O ile w przypadku pierwszej wyspy było to możliwe, ponieważ znajdowała się pod kontrolą Franków, to w przypadku Sardynii nie można powiedzieć nic pewnego o jej przynależności. W przypadku Sycylii wzmianka w dokumencie jest zapewne tylko wyrazem roszczeń, ponieważ pozostawała ona pod kontrolą bizantyńską. Całkiem możliwe, że Karol zgodził się manifestacyjnie ofiarować ją papiestwu, po wycofaniu się z sojuszu z Bizancjum w 787 r. i zerwaniu zaręczyn jego córki Rotrudy z cesarzem Konstantynem VI ${ }^{54}$.

Wywód Thomasa Noble’a na temat treści Pactum Ludovicianum, w dużej mierze tu odtworzony, posiada jednak pewne wady. Autor zauważa, że nawet jeśli założyć, iż w 781 i $787 \mathrm{r}$. doszło do potwierdzenia starych i nadania nowych darowizn, to w praktyce postanowienia te były trudne do wyegzekwowania. Tak było chociażby w przypadku egzarchatu, gdzie w dalszym ciągu arcybiskup Rawenny nie chciał podporządkować się władzy papieskiej ${ }^{55}$. Hadrian nie utrzymał także kontroli nad zdobytą w 787 r. częścią Kampanii. Papież nie mógł kontrolować również należących do Bizancjum Sycylii, Neapolu i Kalabrii. Noble zdaje się jednak twierdzić, że Hadrianowi przekazano w $781 \mathrm{r}$. kontrolę nad całą Sabiną, a nie tylko nad znajdującymi się na jej terytorium dawnymi kościelnymi patrymoniami ${ }^{56}$. Trudno jednak stwierdzić, jak było w rzeczywistości, ponieważ określenie terytorium używane w kontekście tego obszaru w Pactum Ludovicianum nie dowodzi przekonywająco, że Karol Wielki w całości scedował go papieżowi. Niezależnie jednak od tego, jaki charakter miała darowizna, bez wątpienia przejęcie Sabiny przez Rzym napotkało trudności, o czym świadczą informacje z Codex Carolinus.

50 Na temat politycznych uwarunkowań chrztu Pepina zob. A. Pieniądz, Tradycja i wtadza. Królestwo Wtoch pod panowaniem Karolingów 774-875, Wrocław 2007, s. 71-73.

51 W kontekście Benewentu, Spoleto, Neapolu i Kalabrii termin patrymonium należy rozumieć najpewniej tak samo, jak w kontekście wymienionej wcześniej Sabiny.

52 Pactum, s. 353; T.F.X. Noble, The Republic of St. Peter..., s. 175-180.

53 Pactum, s. 353.

54 T.F.X. Noble, The Republic of St. Peter.., s. 172-174.

55 Tamże, s. 168-172.

56 Tamże, s. 157-159. 
Możliwe jednak, że Hadrian uzyskał w końcu jakieś koncesje na tym obszarze, kiedy Karol osadził w Spoleto książąt pochodzenia frankijskiego, niewątpliwie bardziej posłusznych niż longobardzcy poprzednicy. Noble sugeruje też, że papiestwu udało się na stałe włączyć do swych posiadłości część Kampanii przekazaną w 781 r. ${ }^{57}$ Ustalenie, czy papiestwo objęło nad nią trwałą zwierzchność, w rzeczywistości jest natomiast trudne, ponieważ krnąbrni władcy Benewentu niezbyt liczyli się z Frankami i papiestwem. W przypadku części longobardzkiej Toskanii wydaje się jednak, że rzeczywiście została ona przekazana Hadrianowi, tak jak twierdzi Noble. Jej granica nie sięgała bowiem tak daleko na północ jak ta wymieniona w Liber Pontificalis. Tak ograniczone ustępstwo mogło być więc wyrazem kompromisu, możliwego do realizacji dla króla.

\section{PODSUMOWANIE}

Dokładne ustalenie, nad jakimi obszarami Państwo Kościelne sprawowało rzeczywistą kontrolę w II połowie VIII w., jest zadaniem niełatwym. W latach 756-774 nowe formalne nabytki terytorialne były trudne do opanowania i utrzymania ze względu na wrogą działalność monarchii Longobardów, niechęć do interwencji zbrojnych prezentowaną przez Franków oraz opór arcybiskupa Rawenny. Po 774 r. i upadku longobardzkiej monarchii głównymi czynnikami utrudniającymi przejęcie przez papiestwo kontroli nad nowymi nabytkami stały się natomiast opór postlongobardzkich elit świeckich, o których przychylność zabiegali Frankowie, oraz wciąż silny raweński separatyzm.

Między 756 a 774 r. pod kontrolą papieża znajdował się na pewno teren dukatu rzymskiego (na pewno z rzymską Toskanią i przypuszczalnie także z rzymską Kampanią) i prawdopodobnie dukat Perugii, choć ta druga kwestia nie jest wystarczająco naświetlona w źródłach i założenie to ma charakter hipotetyczny. Informacje o lekceważeniu kurii rzymskiej przez hierarchię kościelną Rawenny pozwalają sądzić, że papiestwo miało problemy z wyegzekwowaniem swojej władzy na obszarze właściwego egzarchatu Rawenny i części dukatu Pentapolis, przekazanych Stolicy Apostolskiej przez króla Franków Pepina Małego na mocy układów z lat 755-756, odnotowanych w Liber Pontificalis. Fiaskiem zakończyły się też starania papiestwa o dukat Ferrary i Ankonę (plenaria iustitiae), które obiecał w 757 r. przekazać mu król Longobardów Dezyderiusz, nie dotrzymując jednak obietnicy.

Po likwidacji królestwa Longobardów w 774 r. król Franków Karol Wielki potwierdził darowizny swego ojca Pepina i obiecał przekazać Państwu Kościelnemu nowe terytoria, czego świadectwem jest tekst Liber Pontificalis. Realizacja tego porozumienia również napotkała przeszkody, co odzwierciedla korespondencja papieska zawarta w zbiorze Codex Carolinus oraz tekst dokumentu Pactum Ludovicianum. Pewne jest, że pod koniec VIII w. Państwo Kościelne kontrolowało obszary dawnych dukatów rzymskiego (pomijając sporną kwestię rzymskiej Kampanii) i Perugii. Bardzo prawdopodobne jest też, że papież Hadrian po 781 r. opanował południową część

Tamże, s. 165 . 
longobardzkiej Toskanii, okrojoną względem nabytków w tym regionie przyznanych formalnie w 774 r. Być może papiestwo kontrolowało również Korsykę. Opór arcybiskupów Rawenny w dalszym ciągu wydatnie utrudniał jednak papieżowi kontrolę nad właściwym egzarchatem oraz dukatami Ferrary i Pentapolis. Trudno powiedzieć cokolwiek pewnego o ewentualnej zwierzchności papiestwa nad Sardynią. Nie wiadomo też, jaki charakter miała ewentualna władza papieska w Sabinie (pełna zwierzchność polityczna czy prawo do dochodów) i czy w ogóle papiestwu udało się wyegzekwować jakiekolwiek prawa do niej. Trudno powiedzieć też, czy Rzym utrzymał kontrolę nad częścią Kampanii przekazaną mu w 781 r. Na pewno stracił natomiast szybko część Kampanii uzyskaną w 787 r. Papiestwo na pewno nie kontrolowało (choć obszary te pojawiają się w tym kontekście w analizowanych źródłach) bizantyńskiej Sycylii, praktycznie niepodległej już Wenecji oraz dopiero podbijanej przez Franków Istrii. Rzym na pewno nie posiadał też władzy nad księstwami Benewentu i Spoleto (może poza jakimiś patrymoniami). Papiestwo zapewne nie mogło również uzyskać patrymoniów w kontrolowanych jeszcze przez Bizancjum Neapolu i Kalabrii.

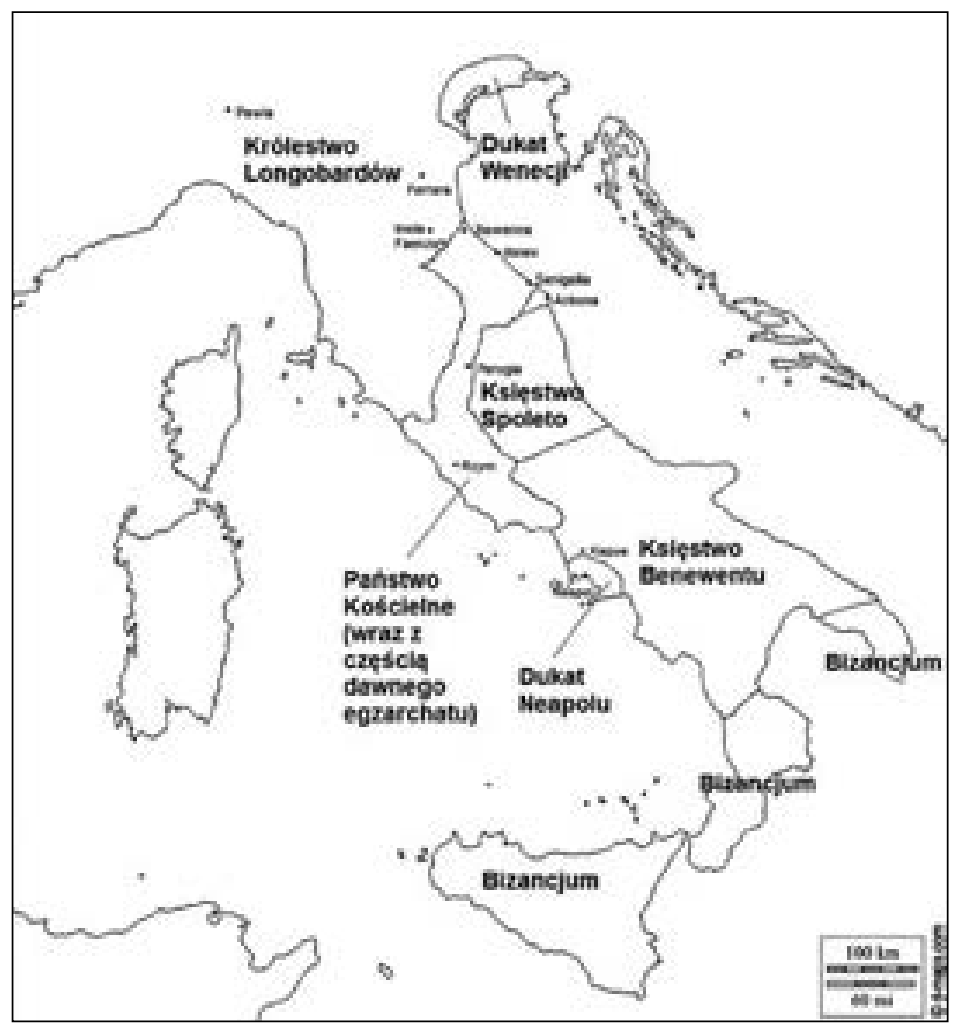

Prawdopodobny podział polityczny Italii w 756 r. (obszar Państwa Kościelnego wraz z uwzględnieniem przekazanej przez Franków części dawnego egzarchatu Rawenny). Mapa konturowa, na podstawie której przygotowano powyższe przedstawienie, została zaczerpnięta z serwisu d-maps.com (https://d-maps.co$\mathrm{m} / \mathrm{m} /$ europa/italia/italie/italie02.gif, 18 VII 2019) 


\section{BIBLIOGRAFIA}

\section{Źródła}

Codex Carolinus, [w:] Monumenta Germaniae Historica, Epistolae (3), Epistolae Merowingici et Karolini aevi (I), red. W. Gundlach, Berolini 1892.

Liber Pontificalis I-XCVI (usque ad annum 772) [Ksiega Pontyfików 1-96 (do roku 772)], tekst łaciński i polski, przeł. P. Szewczyk, M. Jesiotr, Kraków 2014.

Liber Pontificalis XCVII-CXII (ann. 772-891) [Księga Pontyfików 97-112 (772-891)], tekst łaciński i polski, przeł. A. Caba, B. Frontczak, M. Jesiotr, Kraków 2015.

Pactum Hludovicii Pii cum Paschali pontefice, [w:] Monumenta Germaniae Historica, Capitularia regum Francorum (1), Additamenta ad Hludowici Pii et Hlotharii Capitularia (XI), red. A. Boretius, Hannoverae 1883.

\section{Opracowania}

Borri F., Duces e magistri militum nell'Italia esarcale (VI-VIII secolo), „Reti Medievali Rivista” 2005, nr 2, https://doi.org/10.6092/1593-2214/187.

Capo L., Il Liber Pontificalis, I longobardi e la nascita del dominio territoriale della chiesa romana, Spoleto 2009.

Daileader P., One Will, One Voice, and Equal Love: Papal Elections and the "Liber Pontificalis" in the Early Middle Ages, „Archivum Historiae Pontificiae” 1993, vol. 31.

Dvornik F., Bizancjum a prymat Rzymu, przeł. M. Radożycka, Warszawa 1985.

Fałkowski W., Wielki Król. Ideologiczne podstawy wtadzy Karola Wielkiego, Warszawa 2011.

Goodson C., The Rome of Pope Paschal I: Papal Power, Urban Renovation, Church Rebuilding and Relic Translation, 817-824, Cambridge 2010.

Gordziałkowski J., Historia Państwa Kościelnego, Kraków 2007.

Hallenbeck J.T., Instances of Peace in Eighth-century Lombard-Papal Relations, „Archivum Historiae Pontificiae" 1980, vol. 18.

Hallenbeck J.T., Paul Afiarta and the Papacy: An Analysis of Policy in Eighth-Century Rome, „Archivum Historiae Pontificiae” 1974, vol. 12.

Hallenbeck J.T., Pavia and Rome: The Lombard Monarchy and the Papacy in the Eighth Century, Philadelphia 1982.

Hallenbeck J.T., Pope Stephen III. Why Was He Elected?, „Archivum Historiae Pontificiae” 1974, vol. 12.

Jasper D., Fuhrmann H., Papal Letters in the Early Middle Ages, Washington D.C. 2001.

Kumor B., Historia Kościota, t. 2: Wczesne średniowiecze chrześcijańskie, Lublin 2001.

Llewellyn P., The Popes and the Constitution in the Eighth Century, „The English Historical Review" 1986, nr 101 (398), https://doi.org/10.1093/ehr/CI.CCCXCVIII.42.

Llewellyn P., The Roman Church on the Outbreak of Iconoclasm, [w:] Iconoclasm, red. A. Bryer, J. Herrin, Birmingham 1975.

Marazzi F., Il conflitto fra Leone III Isaurico e il papato fra il 725 e il 733, e il 'definitivo' inizio del medioevo a Roma: un'ipotesi in discussione, „Papers of the British School at Rome” 1991, vol. 59, https://doi.org/10.1017/S0068246200009727. 
McCormick M., Bizancjum zperspektywy Zachodu, [w:] Bizancjum ok. 500-1024, red. J. Shepard, przeł. K. Pachniak, J.S. Partyka, R. Piotrowski, Warszawa 2012.

McKitterick R., Królestwa Karolingów. Wtadza, konflikty, kultura - 751-987, przeł. B. Hlebowicz, M. Wilk, Warszawa 2011.

Miller D.H., Papal-Lombard Relations during the Pontificate of Pope Paul I: The Attainment of an Equilibrium of Power in Italy, 756-767, „The Catholic Historical Review” 1969, vol. 55, nr 3 .

Miller D.H., The Roman Revolution of the Eighth Century: A Study of the Ideological Background of die Papal Separation from Byzantium and Alliance with the Franks, "Mediaeval Studies” 1974, vol. 36, https://doi.org/10.1484/J.MS.2.306158.

Noble T.F.X., New Look at the Liber Pontificalis, „Archivum Historiae Pontificiae” 1985, vol. 23.

Noble T.F.X., The Republic of St. Peter. The Birth of the Papal State 680-825, Philadelphia 1986.

Pieniądz A., Tradycja i wtadza. Królestwo Wtoch pod panowaniem Karolingów 774-875, Wrocław 2007.

Ravegnani G., I bizantini in Italia, Bologna 2004.

Sefton D.S., Pope Hadrian I and the Fall of the Kingdom of the Lombards, „The Catholic Historical Review” 1979, vol. 65, nr 2.

Zanini E., Le Italie bizantine. Territorio, insediamenti ed economia nella provincia bizantina d'Italia (VI-VIII secolo), Bari 1998.

Zientara B., Świt narodów europejskich. Powstawanie świadomości narodowej na obszarze Europy postkarolinskiej, wyd. 2, Warszawa 2017.

Бородин О.Р., Равеннский Экзархат. Византийцы в Италии, Санкт-Петербург 2001.

\section{Wykaz skrótów}

CC - Codex Carolinus

LP - Liber Pontificalis

Pactum - Pactum Hludovicii Pii cum Paschali pontefice

Maciej DAWCZYK - doktorant w Katedrze Historii Bizancjum Instytutu Historii Uniwersytetu Łódzkiego. Jego zainteresowania dotyczą historii późnego antyku i wczesnego średniowiecza oraz relacji Bizancjum z germańskimi królestwami zachodniej Europy. Przygotowywana rozprawa doktorska dotyczy relacji bizantyńsko-longobardzkich w VI-VIII w. 